Volume 6 No. 1 April 2019

P-ISSN 2355-2700 E-ISSN 2550-0139

http://ejournal.bsi.ac.id/ejurnal/index.php/moneter

\title{
Penerapan Zahir Accounting Versi 5.1 Dalam Penyusunan Laporan Keuangan Pada PT. Citarum Borneo Quantum
}

\author{
Dian Indah Sari ${ }^{1}$, Rizky Ulya ${ }^{2}$ \\ ${ }^{1}$ Universitas BSI Bekasi \\ e-mail: dian.dhr@bsi.ac.id \\ ${ }^{2}$ Universitas BSI Cikarang \\ e-mail: Iya.cbq@gmail.com
}

Sari, D. I., \& Ulya, R. (2019). Penerapan Zahir Accounting Versi 5.1 Dalam Penyusunan Laporan Keuangan Pada PT. Citarum Borneo Quantum. Moneter, 6(1), 23-32.

\begin{abstract}
Manually accounting processing has more risks than using a computerized system, because accounting requires a confidential database so all existing transactions are related to the finances of a company or individual entity. For example, in the simplest case, which is journal entry, it often occurs double input with the same number or voucher code for different transactions. This has an impact on the normal balance and financial statements that will be made. In order to collect data to fulfill the preparation of this application program, the authors conducted several ways, namely: Observation Method, This method is done by the author is to directly visit the location of the company and collect accounting transaction evidence and observe the process that has been running, so that the author can apply it to Zahir Accounting. Interview, the author conducted interviews with employees of PT. Citarum Borneo Quantum to obtain information on the history of the company, the process of recording accounting transactions from capital, sales, purchases, and financial statements. Library Study Method, carried out by reading books related to accounting transactions and related to the material of Programming Using Zahir Accounting Version 5.1. Based on the results of the discussion it can be concluded as follows: Application of Zahir Accounting Version 5.1 in preparing financial statements will produce computerized financial reports. The company was greatly helped by the application of Zahir Accounting Version 5.1 because it recorded financial transactions and financial reporting quickly, accurately and efficiently.
\end{abstract}

Keywords: Zahir, Accounting, Financial Report

\section{PENDAHULUAN}

Teknologi membawa pengaruh yang cukup besar pada dunia pendidikan dan bisnis. Salah satu bentuk teknologi itu adalah komputer. Karena sistem komputer sekarang mulai banyak diterapkan didunia pendidikan dan diaplikasi bisnis, baik itu bisnis skala besar maupun bisnis skala kecil. Hal ini disebabkan komputer merupakan alat yang dibutuhkan oleh suatu perusahaan yang dapat membuat data lebih cepat, akurat, tepat waktu, serta penghematan ruang penyimpanan sehingga mempermudah penyimpanan dan pengambilan data kembali.

Dalam rangka meningkatkan kinerja suatu perusahaan, penggunaan komputer dan sistemsistemnya sudah menjadi kebutuhan yang sangat penting karena proses manual dari perusahaan dapat digantikan oleh komputer. Tetapi dalam kenyataannya banyak perusahaan-perusahaan yang belum menggunakan hal tersebut. Hal ini disebabkan karena beberapa faktor, diantaranya penggunaan sistem di dalam suatu perusahaan membutuhkan budget yang tidak sedikit.
Pengolahan akuntansi secara manual memiliki lebih banyak resiko dibandingkan dengan menggunakan sistem yang terkomputerisasi, karena akuntansi memerlukan database yang confidential maka seluruh transaksi yang ada berkaitan dengan keuangan sebuah perusahaan atau badan perseorangan. Misalkan dalam hal yang paling sederhana yaitu penginputan jurnal, seringkali terjadi double input dengan nomor atau kode voucher yang sama untuk transaksi yang berbeda. Hal ini berdampak pada saldo normal dan laporan keuangan yang akan dibuat. Maka didalam penelitian ini, penulis mencoba menerapkan sebuah program aplikasi pencatatan akuntansi pada PT. CITARUM BORNEO QUANTUM dengan mengambil judul "Penerapan Zahir Accounting Versi 5.1 Dalam Penyusunan Laporan Keuangan Pada Pt. Citarum Borneo Quantum”.

\section{Pengertian Akuntansi}

Menurut Lubis (2017:1) menyimpulkan, bahwa "Akuntansi adalah seni pencatatan, pengelompokan, atau pengikhtisaran dan pelaporan yang disajikan 
dalam laporan keuangan yang berisi sumber-sumber informasi ekonomi yang berguna untuk pengambilan keputusan bagi pihak-pihak yang berkepentingan". tulisan merupakan inovasi terbaru.(Han \& Kamber, 2006)

Menurut Christiyanto \& Wahyono (2016) menyimpulkan, bahwa "Akuntansi merupakan kumpulan konsep dan teknik ynag digunakan untuk mengukur dan melaporkan informasi keuangan dalam satu unit usaha ekonomi”.

Menurut Bimantara (2017) menyimpulkan, bahwa "Pengertian akuntansi merupakan proses yang terdiri dari identifikasi, pengukuran, dan pelaporan informasi ekonomi”.

\section{Konsep Dasar Akuntansi}

Menurut Hery (2015:10) menyimpulkan, bahwa "Dalam proses kegiatannya akuntansi berlandaskan pada asumsi-asumsi tertentu". Dalam asumsi ini timbul konsep dalam akuntansi. Konsep-konsep akuntansi adalah sebagai berikut:
a. Konsep Entitas Usaha (Accounting Entity Concept)
b. Konsep Biaya / Harga Pertukaran (Historical Cost Concept)
c. Konsep Kontinuitas Usaha (Going Concern Concept)
d. Konsep Penandingan (Matching Cost And Revenues)
e. Konsep Pengukuran Uang (Money Measuring Unit)
f. Konsep Periode Akuntansi (Periodicity)
1) Cash Basis (Dasar Kas)
2) Accrual Basis (Dasar Akrual)

\section{Siklus Akuntansi}

Menurut Lubis (2017:11) menyimpulkan, bahwa "Dalam proses menghasilkan informasi yang dibutuhkan oleh berbagai pihak yang berkepentingan, akuntansi harus melewati beberapa tahapan proses". Proses tersebut dimulai dari mengumpulkan dokumen dasar transaksi, mengklasifikasikan jenis transaksi, menganalisis, meringkasnya dalam catatam, sehingga melaporkannya dalam bentuk laporan keuangan yang dibutuhkan, yang disebut siklus akuntansi seperti gambar berikut:

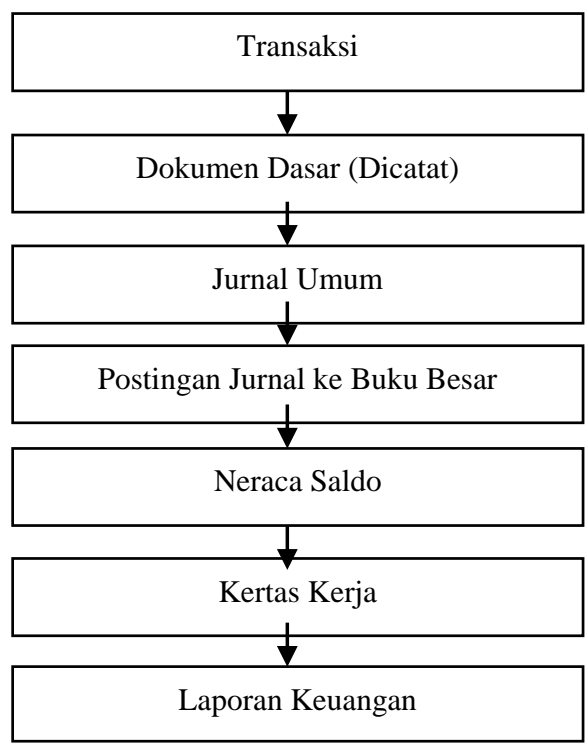

Sumber: Lubis (2017:12)

Gambar 1 Siklus Akuntansi

\section{Laporan Keuangan}

Menurut Lubis (2017:13) menyimpulkan, bahwa "Laporan keuangan adalah hasil akhir dari pencatatan yang merupakan suatu ringkasan dari transaksitransaksi keuangan yang terjadi selama tahun buku yang bersangkutan".

Laporan keuangan terdiri dari:

a. Laporan Laba Rugi (L/R)

Laporan L/R menginformasikan hasil usaha perusahaan dalam suatu periode tertentu.

b. Laporan Perubahan Ekuitas

Laporan perubahan ekuitas adalah laporan keuangan yang menunjukkan perubahan ekuitas selama satu periode.

c. Neraca

Neraca menginformasikan posisi keuangan pada saat tertentu yang tercermin pada jumlah harta yang dimiliki serta jumlah dan modal perushaan selama satu periode akuntansi.

d. Laporan Arus Kas

Laporan arus kas menginformasikan perubahan dalam posisi keuangan sebagai akibat dari kegiatan usaha, pembelanjaan, dan investasi selama periode yang bersangkutan .

e. Catatan Atas Laporan Keuangan

Catatan atas laporan keuangan menginformasikan kebijakan akuntansi yang mempengaruhi posisi keuangan dari keuangan perusahaan.

\section{Teori Zahir Accounting}

Menurut Himayati (2013:2) menyimpulkan bahwa "Zahir accounting adalah sebuah program akuntansi yang didesain khusus untuk mengelola keuangan perusahaan secara mudah, fleksibel, yang berfasilitas lengkap dan dapat digunakan untuk berbagai macam perusahaan, baik perusahaan jasa maupun perusahaan dagang". 


\section{METODOLOGI PENELITIAN}

Dalam rangka pengumpulan data untuk memenuhi penyusunan program aplikasi ini, penulis melakukan beberapa cara yaitu:

1. Metode Observasi (Observation Method)

Metode ini yang dilakukan penulis adalah dengan langsung mengunjungi lokasi dimana PT. Citarum Borneo Quantum berlokasi di Ruko Easton Commercial Centre, Jl. Gunung Panderman Blok A No 7 - Lippo Cikarang Bekasi - Jawa Barat, kemudian penulis mengumpulkan bukti transaksi akuntansi dan mengamati proses yang sudah berjalan, agar penulis bisa menerapkannya ke dalam Zahir Accounting.

2. Wawancara (Interview Method)

Penulis melakukan wawancara dengan karyawan PT. Citarum Borneo Quantum untuk mendapatkan informasi sejarah perusahaan, proses pencatatan transaksi akuntansi dari modal, penjualan, pembelian, sampai laporan keuangan tersaji.

3. Metode Studi Pustaka (library Method)

Selain dengan observasi analis sistem juga melakukan pencarian data dengan metode studi pustaka sebagai pedoman pengumpulan dan mengkaji data yang ada. Metode studi pustaka yang dilakukan dengan membaca buku-buku yang berkaitan dengan transaksi akuntansi dan berhubungan dengan materi Pemograman Menggunakan Zahir Accounting Versi 5.1.

\section{HASIL DAN PEMBAHASAN}

\section{Tinjauan Perusahaan}

PT. Citarum Borneo Quantum adalah perusahaan yang bergerak dibidang jasa, khususnya tambang batu bara. Adapun bisnis seperti perusahaan ini mempunyai saingan-saingan yang bergerak dalam bidang yang sama. PT. Citarum Borneo Quantum memiliki Surat Izin Usaha Perdagangan (SIUP) kecil dengan nomor izin usaha 503.09/1-794/BPMPPT/PK-01/V/2016. Dalam menjalankan usahanya perusahaan PT. Citarum Borneo Quantum belum menggunakan program komputerisasi.

Tabel 1

PT. Citarum Borneo Quantum

Daftar Dan Saldo Awal Akun

01-Jan-17

\begin{tabular}{lll}
\hline $\begin{array}{l}\text { NAMA } \\
\text { AKUN }\end{array}$ & DEBET & KREDIT \\
\hline Kas Kecil & 6.276 .969 & \\
\hline $\begin{array}{l}\text { Bank Mandiri } \\
\text { Induk }\end{array}$ & 295.144 .203 & \\
\hline
\end{tabular}

\begin{tabular}{|c|c|c|}
\hline $\begin{array}{l}\text { Piutang } \\
\text { Usaha }\end{array}$ & 3.577 .761 .940 & \\
\hline Persediaan & 272.705 .208 & \\
\hline Uang Muka & 819.189 .425 & \\
\hline Mesin & 8.887 .560 .000 & \\
\hline $\begin{array}{l}\text { Akum } \\
\text { Penyusutan } \\
\text { Mesin }\end{array}$ & & 5.770 .414 .000 \\
\hline $\begin{array}{l}\text { Utang Gaji } \\
\text { Karyawan }\end{array}$ & & 488.839 .200 \\
\hline Utang Usaha & & 275.340 .737 \\
\hline $\begin{array}{l}\text { PPN } \\
\text { Keluaran }\end{array}$ & & 1.221 .808 .464 \\
\hline $\begin{array}{l}\text { Utang Lancar } \\
\text { Lainnya }\end{array}$ & & 38.856 .375 \\
\hline Modal Saham & & 3.768 .017 .403 \\
\hline Laba Ditahan & & 2.295 .361 .566 \\
\hline TOTAL & 13.858.637.745 & 13.858.637.745 \\
\hline
\end{tabular}

Sumber: PT. Citarum Borneo Quantum (2017)

\section{Data Transaksi}

Berikut ini adalah transaksi yang terjadi selama bulan Januari 2017 - Maret 2017 pada PT. Citarum Borneo Quantum :

Tanggal 02 Januari 2017, PT. CBQ membeli Hose Assy secara tunai sebesar Rp. 450.000,-

Tanggal 03 Januari 2017, PT. CBQ membeli tiket untuk perjalanan dinas Bp. Herry Fathamsyah sebesar Rp. 743.439,-

Tanggal 03 Januari 2017, PT. CBQ membuat invoice kepada PT. BUMA No 001/CBQ-INV/I/2017 Rp. 394.093.461,- yang akan dibayar pada tanggal 28 Februari 2017.

Tanggal 05 Januari 2017, PT. CBQ membayar air sebesar Rp. 466.122 dan membayar listrik sebesar Rp. 847.842,-

Tanggal 05 Januari 2017, terjadi pemindah bukuan dari rekening mandiri induk ke kas kecil sebesar Rp. 5.000.000,-

Tanggal 06 Januari 2017, PT. CBQ membayar telpon dan speedy sebesar Rp. 1.080.365

Tanggal 07 Januari 2017, PT. CBQ membeli barang Tricone Bit 7 7/8 jumlah 1 unit harga Rp 19.500.000, ppn 10\% kepada PT. Pusaka Tandi secara kredit syarat pembayaran 30 hari.

Tanggal 18 Januari 2017, PT. CBQ membayar invoice no I084191 PT. Sandvik Mining \& Construction Indonesia sebesar Rp. 20.867.000,-

Tanggal 20 Januari 2017, PT. Bukit Makmur Mandiri membayar invoice no 017/CBQ-INV/XII/2016 sebesar Rp. 580.761.940 kepada PT. CBQ.

Tanggal 23 Januari 2017, PT. CBQ membeli tiket cuti karyawan sebesar Rp. 7.564.447,-

Tanggal 27 Januari 2017, PT. CBQ membayar gaji karyawan HO sebesar Rp. 39.500.000 dan gaji karyawan lapangan Rp. 42.890.000,- 
Tanggal 01 Februari 2017, PT. CBQ membuat invoice kepada PT. BUMA No 006/CBQINV/II/2017 Rp. 707.218.344,- yang akan dibayar tanggal 20 Maret 2017.

Tanggal 02 Februari 2017, PT. CBQ membeli filter ke CV. Aneka Filter sebesar Rp. 5.200.000,- secara tunai.

Tanggal 04 Februari 2017, PT. CBQ membeli oli CX Hydraulic Oil AW jumlah 2 unit harga per unit Rp 5.472.727 Ppn $10 \%$ kepada PT. Petroleum Lima secara kredit dengan syarat pembayaran 30 hari.

Tanggal 05 Februari 2017, terjadi pemindah bukuan dari rek mandiri induk ke kas kecil sebesar Rp. 5.000.000,-

Tanggal 07 Februari 2017, PT. CBQ membayar abodemen parkir sebesar Rp. 160.000,-

Tanggal 10 Februari 2017, PT. CBQ membayar Telpon \& speedy sebesar Rp. 924.578,- dan membayar listrik sebesar Rp. 867.826,-

Tanggal 14 Februari 2017, PT. CBQ membayar tagihan invoice no AS560044100 kepada PT. Trakindo Utama sebesar Rp. 2.170.850.-

Tanggal 14 Februari 2017, PT. CBQ membayar tagihan invoice no I084417 kepada PT. Sandvik Mining \& Construction indonesia sebesar Rp. 35.538.800,-

Tanggal 14 Februari 2017, PT. CBQ membayar air sebesar Rp. 449.522,-

Tanggal 17 Februari 2017, Bp. Herry Fathamsyah meminjam uang perusahaan (pinjaman sementara) sebesar Rp. 10.000.000,-

Tanggal 17 Februari 2017, PT. CBQ membeli barang 7 7/8 Inc F35 Focus TCI jumlah 1 unit harga Rp 27.500.000, ppn 10\% kepada PT. Atlas Copco Nusantara secara kredit dengan syarat pembayaran 30 hari.

Tanggal 27 Februari 2017, PT. CBQ membayar gaji karyawan HO sebesar Rp. 43.700.000,- dan gaji karyawan lapangan sebesar Rp. 41.500.000,-

Tanggal 28 Februari 2017, PT. Bukit Makmur Mandiri Utama membayar invoice no 001/CBQINV/I/2017 kepada PT. CBQ sebesar Rp. 386.928.125,-

Tanggal 02 Maret 2017, PT. CBQ membuat invoice kepada PT. BUMA No 010/CBQ-INV/III/2017 Rp. 634.808.176,- yang akan dibayar pada tanggal 10 April 2017.

Tanggal 05 Maret 2017, PT. CBQ membayar invoice no 049/PTR-BPN/02/2017 kepada PT. Petroleum Lima sebesar Rp. 12.039.999,-

Tanggal 05 Maret 2017, terjadi pemindah bukuan dari rek mandiri induk ke kas kecil sebesar Rp. 5.000 .000

Tanggal 06 Maret 2017, PT. CBQ membayar air sebesar Rp. 420.642,-

Tanggal 07 Maret 2017, PT. CBQ membeli barang Velve Selenoid jumlah 1 unit harga Rp 3.100.000, ppn $10 \%$ kepada CV. Putri Cahata Lestari secara kredit dengan syarat pembayaran 30 hari.

Tanggal 13 Maret 2017, PT. CBQ membayar invoice no FN-1312/BP/EK/I/2017 kepada PT. Pusaka Tandi sebesar Rp. 21.450.000,-

Tanggal 19 Maret 2017, PT. CBQ membayar invoice no 673794 kepada PT. Atlas Copco Nusantara sebesar Rp. 30.250.000,-

Tanggal 20 Maret 2017, Bp. Herry Fathamsyah mengembalikan pinjaman sementara kepada PT. Citarum Borneo Quantum tahap 1 sebesar Rp. 5.000.000,-

Tanggal 20 Maret 2017, PT. CBQ membayar listrik Rp. 551.086,- dan telpon \& speedy Rp. 1.076.975,-

Tanggal 20 Maret 2017, PT. Bukit Makmur Mandiri Utama membayar invoice no 006/CBQ-INV/II/2017 kepada PT. CBQ sebesar Rp. 694.359.829,-

Tanggal 22 Maret 2017, PT. CBQ membayar catering periode Januari 2017 sebesar Rp. 20.780.000,-

Tanggal 24 Maret 2017, PT. CBQ membayar gaji karyawan HO sebear Rp. 43.700.000,- dan gaji karyawan lapangan sebesar Rp. 41.960.000,-

\section{Data Penyesuaian Per-31 Maret 2017}

Beban penyusutan mesin selama 3 bulan Rp. 288.520.701

\section{Pencatatan Dengan Tool Aplikasi}

\section{A. Setup Awal}

Membuat Database Perusahaan

Berikut ini tahap-tahap untuk membuat database perusahaan baru pada aplikasi Zahir Accounting 5.1, yaitu:

Buka Program Zahir 5.1, klik menu - All Apps - Zahir System Standart Edisi Pendidikan System Versi. 5.1 Klik Membuat data baru pada tampilan menu utama Zahir

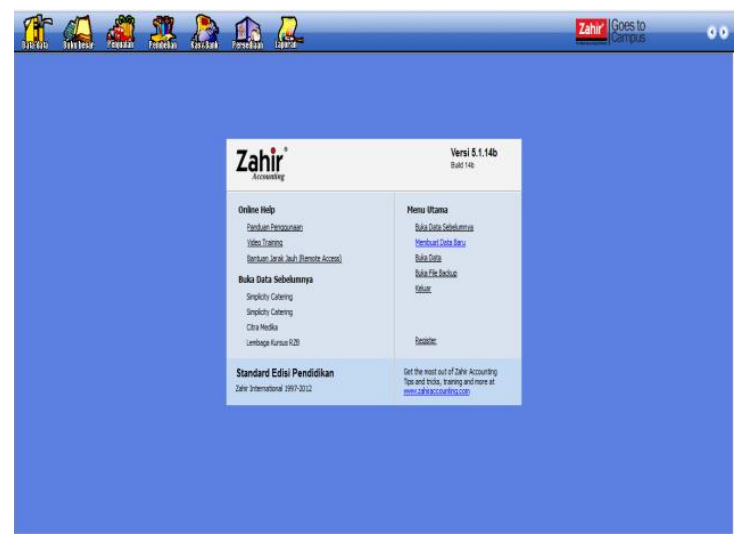

Sumber : Aplikasi Zahir Accounting V. 5.1

Gambar 2 Menu Utama Zahir

\section{B. Input Saldo Awal}

Input Saldo Awal Account

a. Klik Setting - Saldo Awal - pilih Saldo Awal Akun

b. Isikan semua saldo awal yang ada seperti gambar berikut, kemudian Rekam. 
eJournal, Vol 6 No.1 April 2019

P-ISSN 2355-2700 E-ISSN 2550-0139
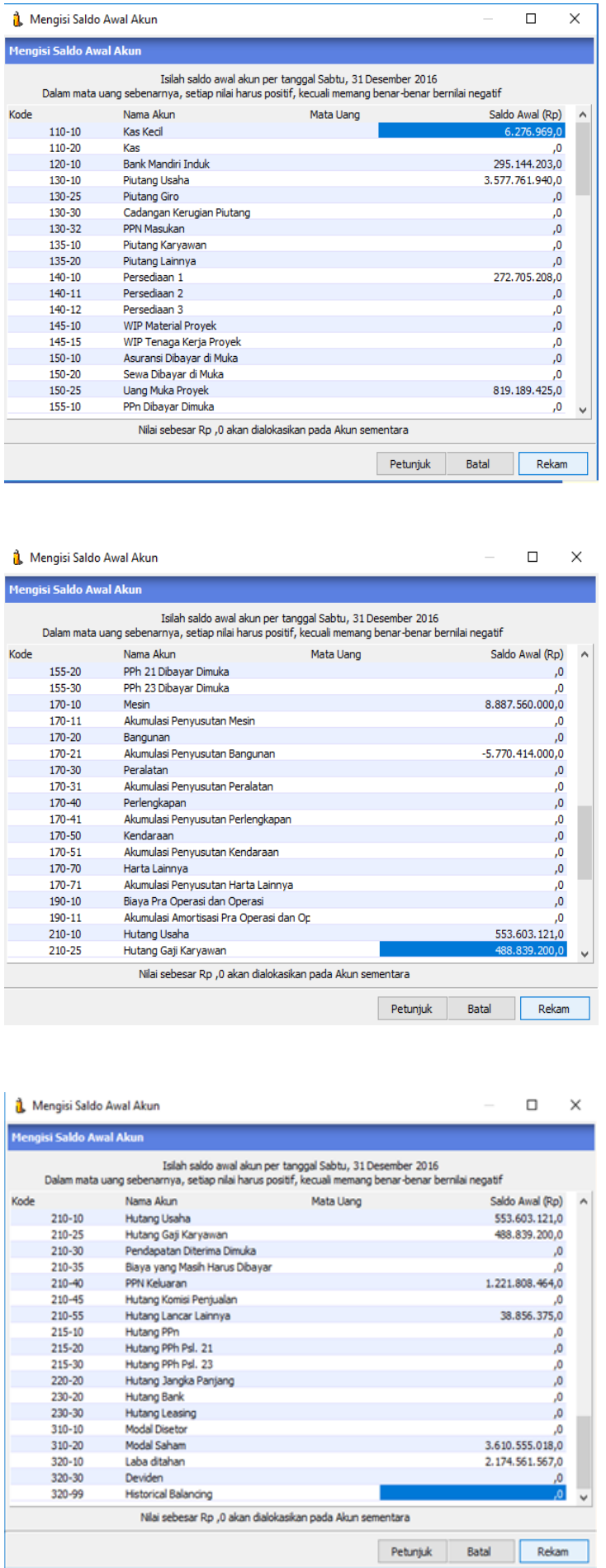

Sumber : Aplikasi Zahir Accounting V. 5.1

Gambar 3 Entri Saldo Awal Akun

Input Saldo Awal Piutang

Klik Setting - Saldo Awal - pilih Saldo Awal Piutang Usaha

Isi semua saldo awal yang ada seperti gambar berikut, kemudian Rekam

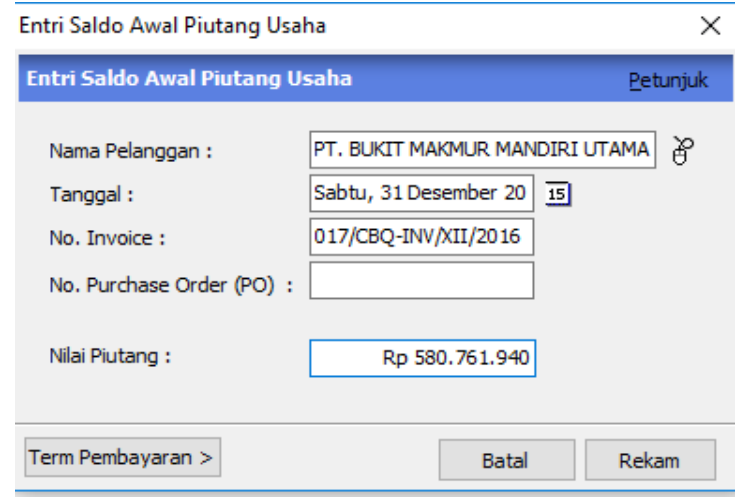

Sumber : Aplikasi Zahir Accounting V. 5.1

Gambar 4 Entri Saldo Awal Piutang

Berikut saldo awal piutang PT. Citarum Borneo Qauntum

\begin{tabular}{|c|c|c|c|}
\hline \multicolumn{4}{|l|}{ Mengisi saldo awal piutang usaha } \\
\hline Nama Pelanggan & Tanggal & No Invoice & Saldo Piutang \\
\hline PT. BUKT MAKMUR MANDIRT UTAMA & $31 / 12 / 2016$ & $017 /$ CBQ-INV $/ X I / 20$ & Rp 580761940,0 \\
\hline PT. Beringin Jaya Abadi & $31 / 12 / 2016$ & Performa 016/CBQ-I & $\operatorname{Rp} 1498500000,0$ \\
\hline PT. Beringin Jaya Abadi & $31 / 12 / 2016$ & Performa 018/CBQ-I & Rp 1498500000,0 \\
\hline
\end{tabular}

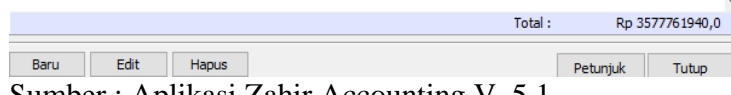

Sumber : Aplikasi Zahir Accounting V. 5.1

Gambar 5 Daftar Saldo Awal Piutang

Input Saldo Awal Hutang

Klik Setting - Saldo Awal - pilih Saldo Awal Hutang Usaha

Isi semua saldo awal yang ada seperti gambar berikut, kemudian Rekam. 


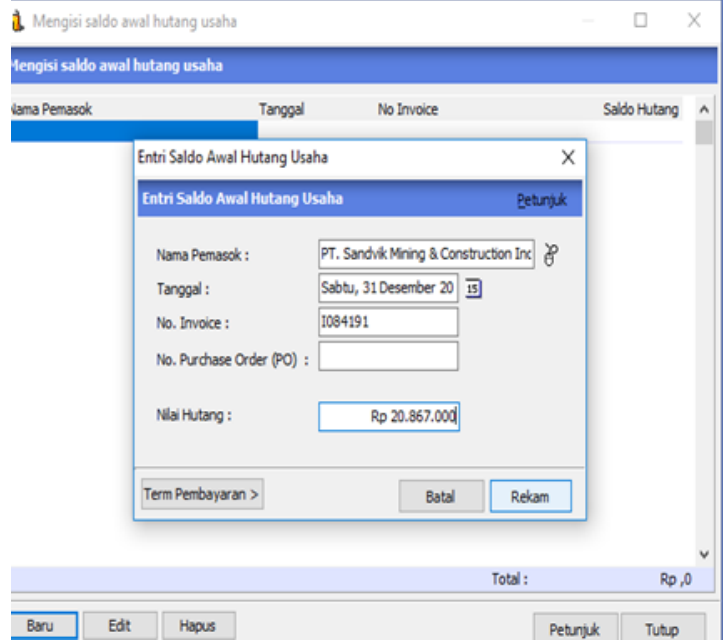

Sumber : Aplikasi Zahir Accounting V. 5.1

Gambar 6 Entri Saldo Awal Utang

Berikut saldo awal utang PT. Citarum Borneo Qauntum

\begin{tabular}{|c|c|c|c|}
\hline \multicolumn{3}{|l|}{ 4. Mengisi saldo awal hutang usaha } & 口 \\
\hline \multicolumn{4}{|l|}{ Mengisi saldo awal hutang usaha } \\
\hline Nama Pemasok & Tanggal & No Invoice & Saldo Hutang \\
\hline PT. Trakindo Utama & $31 / 12 / 2016$ & AS560044100 & Rp 2170850,0 \\
\hline PT. Tridffta Lubrindo & $31 / 12 / 2016$ & 1046/10/TLL/2016 & $\operatorname{Rp} 6658300,0$ \\
\hline PT. Petroleum Lima & $31 / 12 / 2016$ & $381 /$ TR $-B P N / 12 / 20$ & $\operatorname{Rp} 127600000,0$ \\
\hline PT. Mexis & $31 / 12 / 2016$ & 2013MXS-00017 & $\operatorname{Rp} 28560000,0$ \\
\hline PT. Atas Copco Nusantara & $31 / 12 / 2016$ & 669490 & Rp 60500000,0 \\
\hline PT. Tridifta Lubrindo & $31 / 12 / 2016$ & 1044/10/TLL/2016 & $\operatorname{Rp} 21734900,0$ \\
\hline PT. Pusaka Tandi & $31 / 12 / 2016$ & FN-803/PP//EK/16 & Rp 76450000,0 \\
\hline PT. Sandvik Mining \& Construction Indonesia & $31 / 12 / 2016$ & 1084191 & Rp 20867000,0 \\
\hline PT. Sandvik Mining \& Construction Indonesia & $31 / 12 / 2016$ & I084417 & $\operatorname{Rp} 35538800,0$ \\
\hline PT. Power Drillindo & $31 / 12 / 2016$ & 258-INV & Rp 10100887,0 \\
\hline
\end{tabular}

\begin{tabular}{|c|c|c|c|c|c|}
\hline & & & Total: & R & 5340737,0 \\
\hline Baru & Edit & Hapus & & Petunjuk & Tutup \\
\hline
\end{tabular}

Sumber : Aplikasi Zahir Accounting V. 5.1

Gambar 7 Daftar Saldo Awal Utang

\section{Input Data Transaksi}

\section{Menginput Transaksi Kas Keluar}

Untuk menginput kas keluar digunakan Modul Kas \& Bank - Kas Keluar.

Kas keluar digunakan untuk menginput transaksi seperti pembayaran air, listrik, perjalanan dinas, telepon, speedy pembayaran cattering, cuti, pembayara gaji dan lain-lain. Berikut salah satu transaksi kas keluar yang terjadi bulan Januari Maret 2017 pada PT. Citarum Borneo Quantum. Tanggal 05 Januari 2017, PT. CBQ membayar air sebesar Rp. 466.122 dan membayar listrik sebesar Rp. 847.842,-

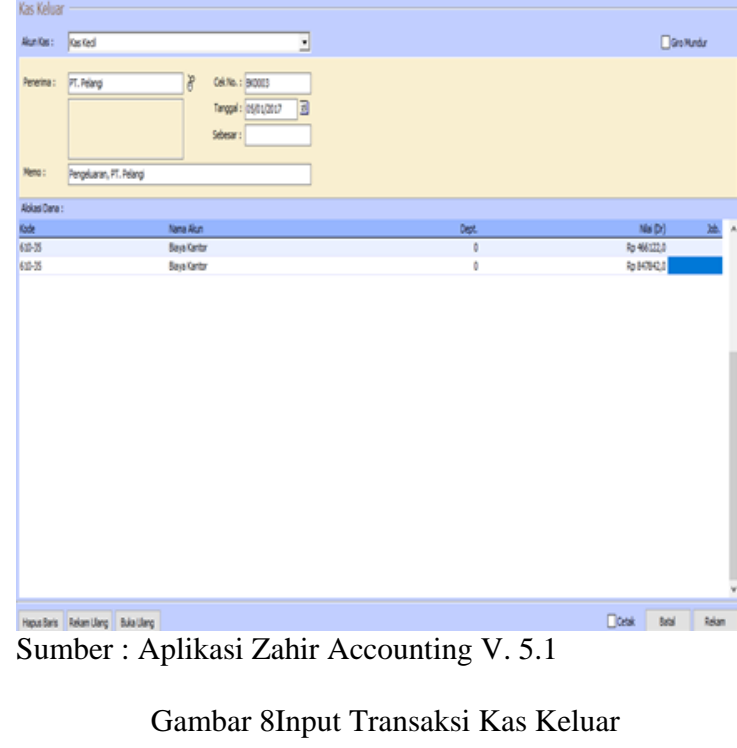

\section{Menginput Transaksi Pembelian}

Setiap terjadi transaksi pembelian dapat diinput melaui transaksi penerimaan barang (invoicing). Transaksi pembelian ini secara otomatis akan membuat jurnal akuntansi, menambah kartu stok dan mengupdate kartu hutang. Isi nama supplier/pemasok, memilih item barang yang akan dibeli, jumlah dan harganya, kemudian klik tombol rekam, semua proses akuntansi akan dibuat secara otomatis.

Pilih modul pembelian - Penerimaan Barang.

a. Kredit

Berikut ini adalah salah satu transaksi pembelian secara kredit pada bulan Januari 2017 PT. Citarum Borneo Quantum.
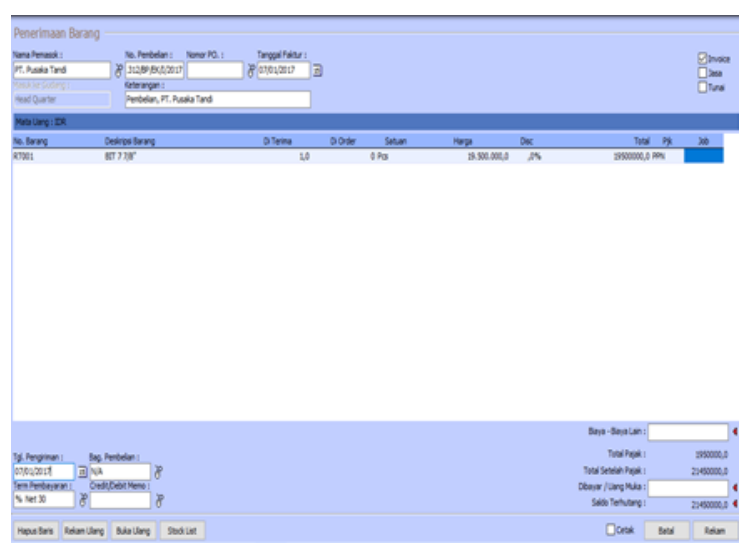

Sumber: Aplikasi Zahir Accounting V. 5.1

Gambar 9 Input Transaksi Pembelian Tunai 
b. Tunai

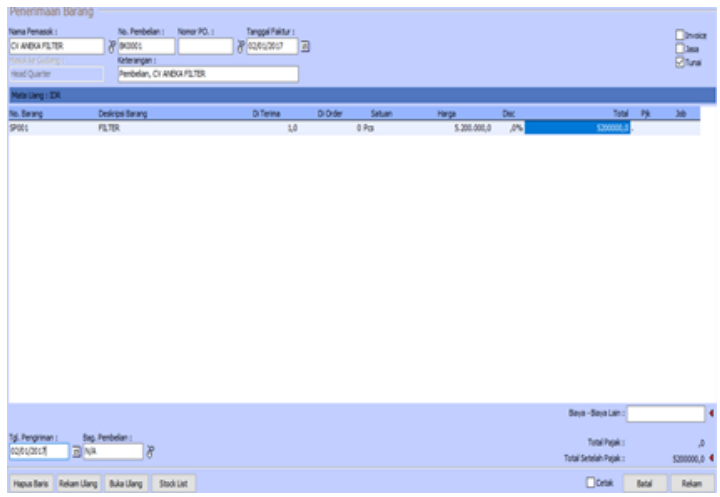

Sumber : Aplikasi Zahir Accounting V. 5.1

Gambar 10 Input Transaksi Pembelian Kredit

\section{Menginput Transaksi Penjualan}

Setiap terjadi transaksi penjualan dapat diinput melalui transaksi pengiriman barang (invoicing). Transaksi penjualan ini secara otomatis akan membuat jurnal akuntansi, mengurangi kartu stok dan mengupdate kartu piutang. Isi nama customer/pelanggan, memilih item barang/jasa yang akan dijual, kemudian klik tombol rekam, semua proses akuntansi akan dibuat secara otomatis. Pilih modul Penjualan - Pengiriman Barang.

Berikut ini adalah salah satu transaksi penjualan kredit yang terjadi bulan januari 2017 pada PT. Citarum Borneo Quantum : Tanggal 03 Januari 2017, PT. CBQ membuat invoice kepada PT. BUMA No 001/CBQ-INV/I/2017 pembayaran net 45 hari sebesar Rp. 394.093.461,-

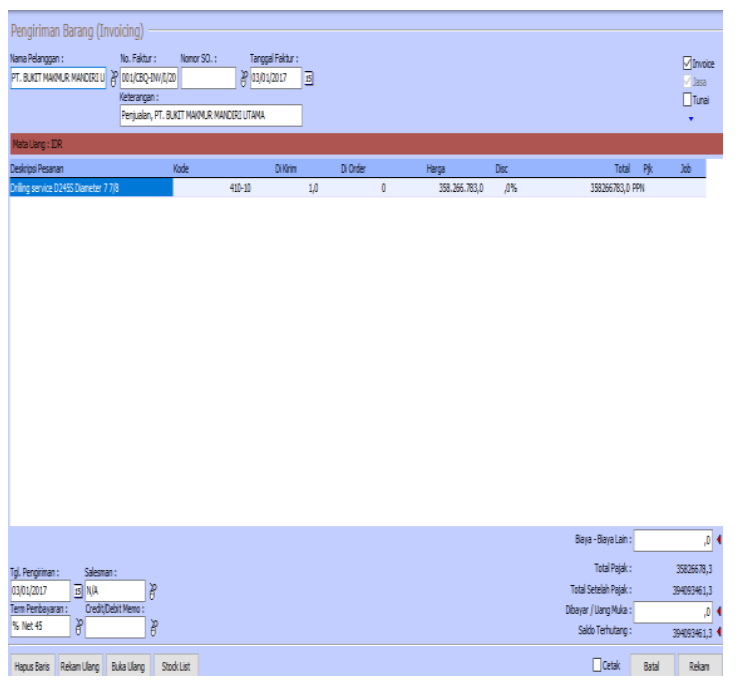

Sumber : Aplikasi Zahir Accounting V. 5.1

Gambar 11 Input Transaksi Penjualan Kredit
Checkmark jasa apabila tidak menggunakan kode barang dan ini untuk perusahaan jasa.

Checkmark invoice agar transaksi otomatis memposting ke Buku Besar. Jika transaksi kredit maka piutang usaha akan dicatat.

\section{Menginput Transaksi Pembayaran Utang}

Untuk menginput transaksi pembayaran hutang dilakukan pada form pembayaran hutang usaha, pilih supplier yang akan menerima pembayaran, kemudian pilih nomor faktur atau invoice mana yang akan dibayar, mengisi discount pembayaran dan denda keterlambatan jika ada.

Tampilan form transaksi pembayaran hutang serupa dengan form transaksi kas keluar, dan sama-sama akan mengurangi saldo rekening kas atau bank, namun tidak diperbolehkan menginput transaksi pembayaran hutang melalui form transaksi kas keluar, karena transaksi kas keluar tidak dapat mengupdate kartu hutang per supplier, transaksi kas keluar hanya membuat jurnal akuntansi saja. Pilih Modul Pembelian Pembayaran - Hutang Usaha.

Berikut salah satu transaksi pembayaran utang yang terjadi bulan Januari 2017 pada PT. Citarum Borneo Quantum : Tanggal 18 Januari, PT. CBQ membayar invoice kepada PT. Sandvik No I084191 sebesar Rp. 20.867.000,-

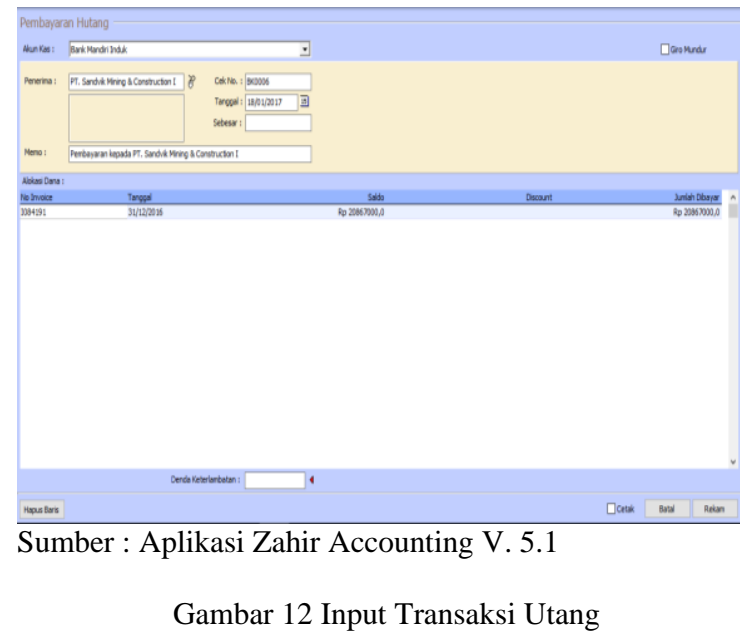

5. Menginput Transaksi Pembayaran Piutang Untuk menginput transaksi pembayaran piutang dilakukan pada form pembayaran piutang usaha, pilih nama customer yang akan melakukan pembayaran, kemudian pilih nomor faktur atau invoice mana yang akan dibayar, mengisi discount pembayaran dan denda keterlambatan jika ada.

Tampilan form transaksi pembayaran piutang serupa dengan form transaksi kas masuk, dan sama-sama akan menambah saldi rekening kas atau bank, namun tidak diperbolehkan menginput transaksi pembayaran piutang melalui form transaksi kas masuk, karena 
transaksi kas masuk tidak dapat mengupdate kartu piutang per customer, transaksi kas masuk hanya membuat jurnal akuntansi saja. Pilih Modul Penjualan Pembayaran - Piutang Usaha.

Berikut ini salah satu transaksi piutang usaha yang terjadi bulan Januari 2017 pada PT. Citarum Borneo Quantum : Tanggal 20 Januari 2017 PT. Bukit Makmur Mandiri membayar invoice no 017/CBQINV/XII/2016 sebesar Rp. 580.761.940,-

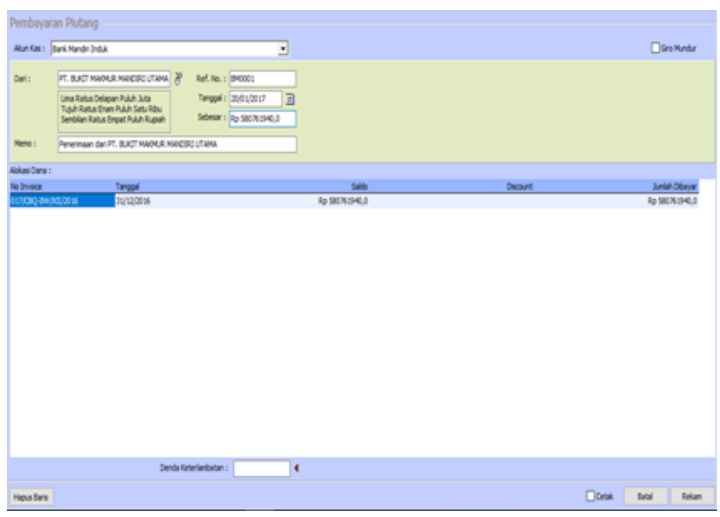

Sumber : Aplikasi Zahir Accounting V. 5.1

Gambar 13 Input Transaksi Pembayaran Piutang

\section{Laporan}

\section{Laporan Laba Rugi}

Klik Modul Laporan - Pilih Laporan Keuangan Pilih Laba Rugi Standar

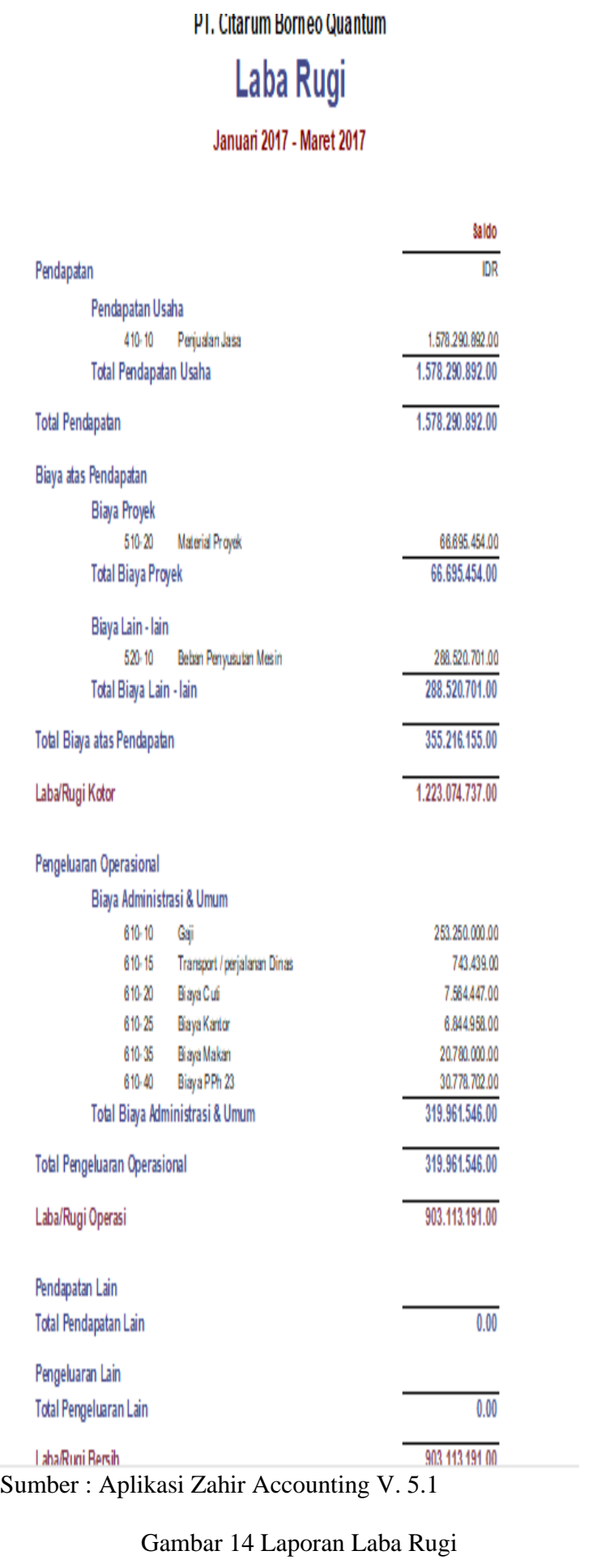

2. Laporan Neraca

Klik Modul Laporan - Pilih Laporan Keuangan Pilih Neraca Standar 


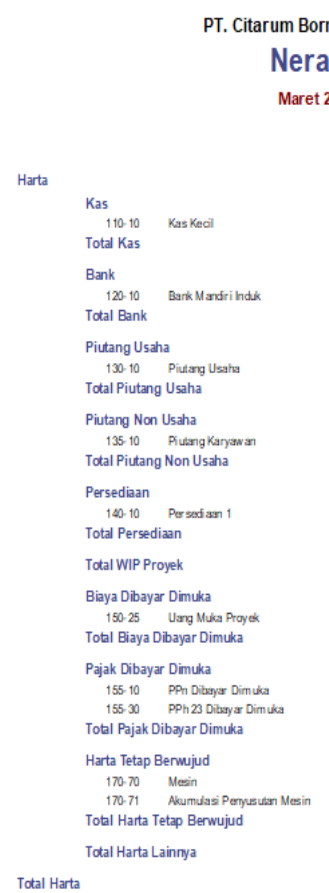

Neraca

Maret 2017

Sumber : Aplikasi Zahir Accounting V. 5.1

Gambar 15 Laporan Neraca Periode Maret 2017

\section{Laporan Penjualan}

Klik Modul Laporan - Laporan Penjualan Penjualan Sederhana

\section{PT.Citirnm Bonneo Quartum}

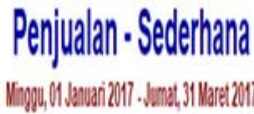

\begin{tabular}{|c|c|c|c|c|c|}
\hline Tangy & b.ref. aderth. & lemapeanyen & Natalang & Jumbeh & $J u m|k| \mid D R$ \\
\hline 0301217 & MICONWW & 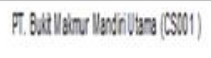 & $D R$ & 3040351:2 & 34.65132 \\
\hline Nonew17 & WaCBD.WW & 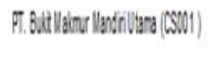 & DR & 10721843430 & m728848\% \\
\hline \multirow[t]{2}{*}{ 003517 } & O10COD.NW & 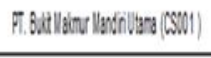 & DR & 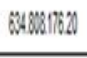 & 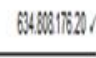 \\
\hline & & Toat: & IDR & & 1.75619091.28 \\
\hline
\end{tabular}

Sumber: Aplikasi Zahir Accounting V. 5.1

Gambar 16 Laporan Penjualan

\section{Laporan Pembelian}

Klik Modul Laporan - Laporan Pembelian Pembelian Sederhana

\section{PT.Citarum Borneo Quantum \\ Pembelian - Sederhana}

Minggu, 01 Januari 2017 - Jumat, 31 Maret 2017

\begin{tabular}{|c|c|c|c|c|c|}
\hline Tanggal & No. Pessnan & VamaPenasook & Mata lang & Jumlah & Jumlah (DR) \\
\hline 0701117 & \multirow{3}{*}{ 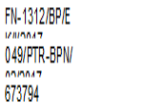 } & PT. Pusska Tand (SPDOS) & IDR & 21.450000000 & 21.450 .000 .002 \\
\hline 040217 & & PT. Petroleun Lima (SPOC3) & IDR & 12.039 .999 .40 & $12.039 .999 .40 \mathrm{~V}$ \\
\hline 1702217 & & PT. Altas Copco Ilussitarara (SPO02) & IDR & 30.250 .000 .00 & $30.250 .000 .00 \mathrm{r}$ \\
\hline 07103417 & \multirow[t]{2}{*}{ PCl-0013 } & W. PutriCAhaya Lesari(SPDO15) & IDR & 3.410000000 & $3.4100000 .00 \mathrm{~J}$ \\
\hline & & & IDR & & 49999,40 \\
\hline
\end{tabular}

Sumber : Aplikasi Zahir Accounting V. 5.1

Gambar 17 Laporan Pembelian

\section{Laporan Daftar Barang}

Klik Modul Laporan - Laporan Barang/Persediaan Daftar Barang Umum

\section{PT. Citerum Borneo Quantum \\ Daftar Barang - Umum}

\begin{tabular}{|c|c|c|c|c|c|}
\hline Kode Barang & Nema Barang & Tersedia Unit & Matid Uany & Harlya Satuan & Total Niliai \\
\hline \multicolumn{6}{|l|}{ Head Quarter } \\
\hline \multicolumn{6}{|l|}{ Rockbds } \\
\hline RTDOO1 & BIT778" & 0.00 Pes & IDR & 0.00 & 0.00 \\
\hline RTT002 & B17778" & 0.00 Pes & DDR & 0.00 & 0.00 \\
\hline \multicolumn{5}{|c|}{ TodalRochthoos: } & 0.00 \\
\hline \multicolumn{6}{|l|}{ Sppre Part } \\
\hline SPTOOO1 & OLl & 0.00 Pes & IDR & 0.00 & 0.00 \\
\hline SPTOOO2 & Velve Selenoid & $0.00 \mathrm{Pcs}$ & IDR & 0.00 & 0.00 \\
\hline \multicolumn{5}{|c|}{ Total Spare Part: } & 0.00 \\
\hline \multicolumn{5}{|c|}{ Todat Head Quarter: } & 0.000 \\
\hline
\end{tabular}

Sumber : Aplikasi Zahir Accounting V. 5.1

Gambar 18 Laporan Daftar Barang

\section{KESIMPULAN}

Berdasarkan hasil pembahasan dapat disimpulkan sebagai berikut :

1. Penerapan Zahir Accounting Versi 5.1 dalam menyusun Laporan Keuangan akan menghasilkan laporan keuangan yang terkomputerisasi.

2. Perusahaan sangat terbantu dengan adanya penerapan Zahir Accounting Versi 5.1 karena pencatatan transaksi keuangan dan pelaporan keuangan cepat, akurat dan efisien 


\section{REFERENSI}

Bimantara, Z. A. (2017). ANALISIS PENGENDALIAN INTERN DALAM SISTEM AKUNTANSI PASIEN UMUM ( Studi Pada Rumah Sakit Ibnu Sina Bojonegoro ), 45(1), 203-209.

Christiyanto, A., \& Wahyono, H. (2016). 1) , 2), 3). Penerapan Aplikasi Komputer Akuntansii, $179-191$.

Han, J., \& Kamber, M. (2006). Data Mining: Concepts and Techniques. Soft Computing (Vol. 54). https://doi.org/10.1007/978-3-64219721-5

Hery. (2015). Pengantar Akuntansi. Jakarta: PT Grasindo.

Himayati. (2013). Eksplorasi Zahir Accounting. (W. Yoevestian, Ed.). Jakarta: PT Elex Media

\section{Komputindo.}

Lubis, R. H. (2017). Cara Mudah Menyusun Laporan Keuangan Perusahaan Jasa. (Maya, Ed.) (1st ed.). Yogyakarta: CV Andi Offset.

Sari, D. I., \& Ulya, R. (2019). Penerapan Zahir Accounting Versi 5.1 Dalam Penyusunan Laporan Keuangan Pada PT. Citarum Borneo Quantum. Moneter, 6(1), 23-32.

\section{PROFIL PENULIS}

DIAN INDAH SARI, SE.AK,MM, memperoleh gelar SE.AK lulus tahun 2000, di Fakultas Ekonomi jurusan Akuntansi ((UNSRI) Universitas Negeri Sriwijaya Palembang. Memperoleh gelar MM, lulus tahun 2014,jurusan Manajemen di Pascasarjana Universitas BSI Bandung. Saat ini bekerja sebagai Dosen di Universitas BSI Bekasi. 